\title{
Measurements of ozone absorption cross section with ratiometric and non-ratiometric methods
}

\author{
Tay Ching En Marcus, Mohd Haniff Ibrahim and Nor Hafizah Ngajikin \\ Department of Communication Engineering, Faculty of Electrical Engineering, \\ Universiti Teknologi Malaysia, 81310 Skudai, Johor, Malaysia
}

Received: 29.01 .2015

\begin{abstract}
In ultraviolet absorption spectroscopy, absorption cross section (ACS) is a parameter important for calculating ozone concentrations. In this work we have determined the ACS at the room temperature and normal pressure. The ozone concentration has been recorded in the region 450-989 ppm, using a compact aluminium gas cell of $5 \mathrm{~cm}$ optical path length. We have also compared the results derived with the ratiometric and non-ratiometric methods based on the Beer-Lambert law. Our experimental results demonstrate that the non-ratiometric method can compete with the ratiometric method whenever the measuring times are relatively short.
\end{abstract}

Keywords: absorption cross section, concentration, gas, ozone, ratiometric method, sensors

PACS: 07.07.Df, 33.20.Kf, 42.25.Bs, 42.79.Pw, 42.81.-i, 78.20.Ci

UDC: $542.7+535.3+681.7$

\section{Introduction}

Absorption cross section (ACS) of ozone is an important parameter used when calculating ozone concentrations with the ultraviolet absorption spectroscopy. The ACS represents a measure of light absorption by ozone. Up to date, there have been numerous reports on the ACS values in the literature, which are not always consistent with each other [1-5]. Of course, the ACS of ozone may easily be obtained through an online gas cell simulator according to the HITRAN 2008 database [6]. However, the ozone ACS is known to depend slightly on temperature and pressure [1, 3, 9]. Therefore the database is accurate enough for specific temperatures and pressures only, whilst in practice the experimental conditions may vary considerably. The ozone ACS is also dependent on the wavelength, because an exact amount of energy is required to excite a molecule of ozone [7, 8]. Summing up, we suppose that further development of different techniques for measuring the ACS is still an urgent task.

In the ultraviolet absorption spectroscopy, the ozone concentration can be measured with either ratiometric or non-ratiometric techniques. Typically, it is derived using a non-ratiometric method. It determines the ozone concentration issuing from comparison of the transmitted intensity $I_{t}$ of light passed through ozone with the incident intensity $I_{0}$ [10-13]. Recently, a ratiometric method has begun to gain popularity for calculating the ozone concentrations. In frame of this technique, the concentration is determined when comparing the intensity passed through ozone, $I_{t}$, with the reference incident intensity $I_{0 r}$ (see Refs. [14-18] for more details). The ratiometric method has been claimed to correct the intensity drifts which can appear since the intensities of broadband light sources vary over time [17]. In other words, the ratiometric method can reliably minimize such system disturbances as an unstable light source power (see Refs. [10, 11, 15]).

The working equation for calculating the ACS in frame of the non-ratiometric method is based on the well-known Beer-Lambert law,

Ukr. J. Phys. Opt. 2015, Volume 16, Issue 1 


$$
\ln \frac{I_{t}}{I_{0}}=-\frac{\sigma N_{A} P l}{10^{6} R T} c .
$$

Here $I_{0}$ is the incident intensity at the wavelength of $260.99 \mathrm{~nm}, I_{t}$ the output intensity at the same wavelength, which has passed through ozone, $\sigma$ the ACS of ozone in $\mathrm{m}^{2}$ molecule ${ }^{-1}, P$ the pressure in atm, $l$ the optical path length in $\mathrm{m}, c$ the concentration of ozone in parts per million by volume (ppm), $T$ the absolute temperature in $\mathrm{K}, N_{A}$ the Avogadro constant $\left(6.02214199 \times 10^{23}\right.$ molecule $\left.\mathrm{mol}^{-1}\right)$, and $R$ the ideal gas constant $\left(8.205746 \times 10^{-5} \mathrm{~atm} \mathrm{~m}^{3} \mathrm{~mol}^{-1} \mathrm{~K}^{-1}\right)$.

When calculating the ACS with the ratiometric method, one can employ a modified Beer-Lambert law,

$$
\ln \frac{I_{t}}{I_{0 r}}=-\frac{\sigma N_{A} P l}{10^{6} R T} c-\ln k .
$$

Here the constant $k$ which modifies the Beer-Lambert law,

$$
k=\frac{I_{0 r}}{I_{0}},
$$

represents in fact the ratio of the intensity $I_{0 r}$ referred to the wavelength of $377.05 \mathrm{~nm}$ to the intensity $I_{0}$ at the working wavelength $(260.99 \mathrm{~nm})$. Such a modification of the Beer-Lambert law is required because the reference $\left(I_{0 r}\right)$ and sampling $\left(I_{0}\right)$ intensities are in general not the same for broadband light sources. This is the reason why the workers in the field often do not determine the ACS using the non-ratiometric method [14-18].

\section{Experimental setup}

First a straight hollow aluminium gas cell of $5 \mathrm{~cm}$ optical path length has been fabricated as shown in Fig. 1. The aluminium gas cell is chosen because it is compatible with dry ozone. Threading can be made for custom fitting with Ocean Optics 74-UV collimating lens. The gas cell has a small inner diameter $(0.64 \mathrm{~cm})$ for fast diffusion of gas throughout the cell. We have chosen a short optical path length because of known peculiarities of the ultraviolet radiation transmission. Notice also that it is important that high enough intensities of light be passed through the empty gas cell.

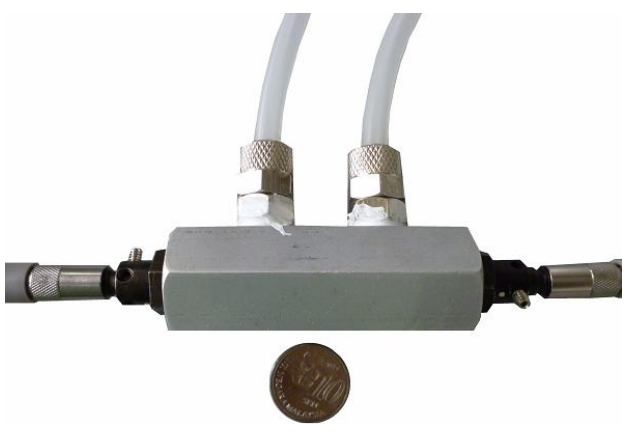

Fig. 1. A photo of our ozone gas sensor based on aluminium gas cell of $5 \mathrm{~cm}$ optical path length shown in comparison to a 10 cent Malaysian coin.

Fig. 2 shows a block diagram of our experimental setup for measuring the ozone ACS. We begin with the 'gas components'. A high-purity (99.999\%) oxygen gas supply is channelled to a corona discharge ozone generator via a vinyl tube. The input flow rate of oxygen to the ozone generator is increased step by step, using a pressure regulator in order to decrease gradually the ozone concentration. This is because the rapidly flowing oxygen would have short residence times in the ozone generator [19]. The ozone thus generated is fed to the aluminium gas cell via a silicone tube, since the silicone is highly resistant to ozone degradation. After that the ozone concentration 
and the pressure are measured by a commercial ozone monitor and recorded by a computer every $10 \mathrm{~s}$. Ozone is being terminated at the monitor which has an inbuilt ozone scrubber.

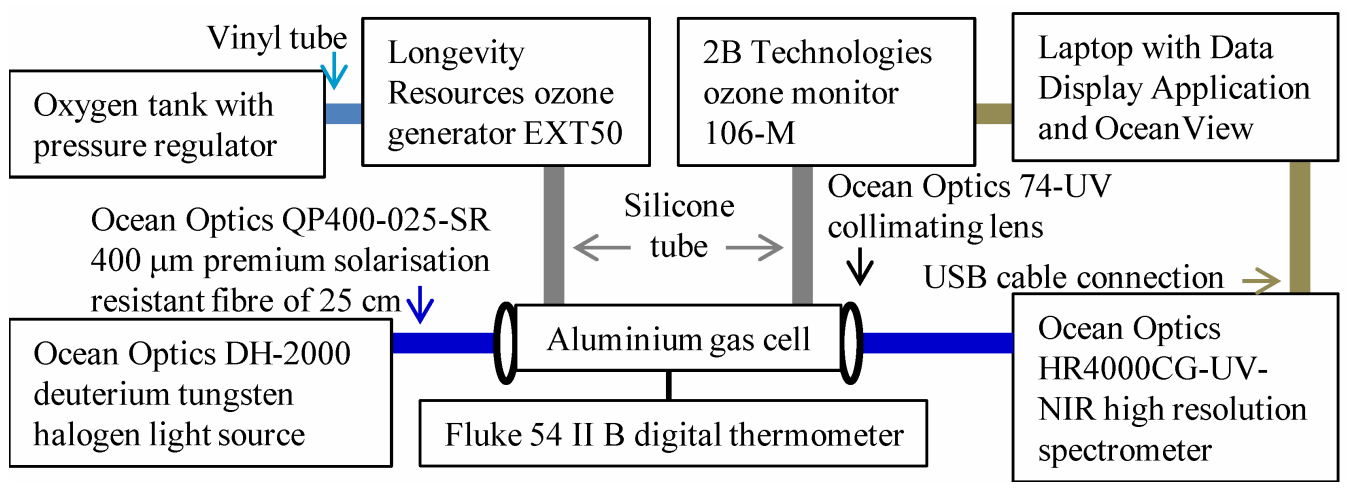

Fig. 2. Block diagram of our experimental setup for measuring the ozone ACS.

Let us now explain the 'light components' of our setup. A deuterium bulb of a deuterium tungsten halogen light source is switched on to deliver the light of wavelengths ranging from 210 to $400 \mathrm{~nm}$. The light is delivered through a premium solarization-resistant fibre, which is specially designed for the ultraviolet applications. The light passes through a collimating lens and the aluminium gas cell so that the light losses are kept to a possible minimum. Finally, the light is collected at a high-resolution spectrometer and analyzed with spectrometer-driving software. The temperature of the aluminium gas cell is measured every $10 \mathrm{~s}$ using a commercial digital thermometer. In addition, the integration time and the averaging rate of the spectrometer are set respectively to $100 \mathrm{~ms}$ and 100 data points so that the intensity of light is recorded every $10 \mathrm{~s}$. This has been made to synchronize our recording system with the ozone monitor that produces readings every $10 \mathrm{~s}$.

\section{Results and discussion}

Fig. 3 displays the experimental transmittance ratio $I_{t} / I_{0}$ versus the wavelength $\lambda$ obtained in our experiments at different readings for the ozone concentration. The minimum transmittances and the maximum absorptions are mostly observed at the wavelength of $260.99 \mathrm{~nm}$. Thus, it would be desirable to choose $260.99 \mathrm{~nm}$ as a working wavelength for the $I_{t}$ and $I_{0}$ intensities in order to sample

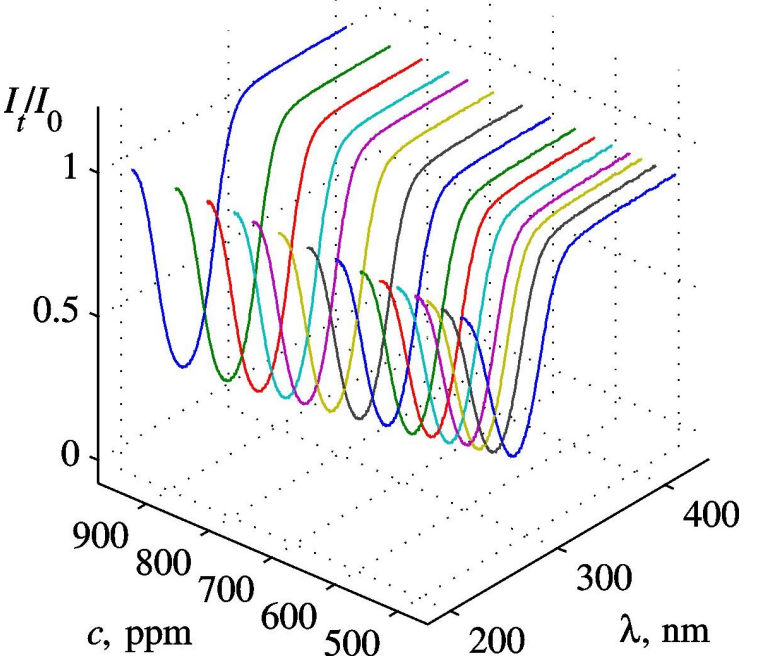

Fig. 3. Dependences of transmittance on the light wavelength, as measured for different ozone concentration readings.

Ukr. J. Phys. Opt. 2015, Volume 16, Issue 1 
ozone with the non-ratiometric method. As seen from Fig. 3, the transmittance at $260.99 \mathrm{~nm}$ is also dependent on the ozone concentration, due to absorption of light by ozone. The shapes of the experimental curves are similar to an 'inverted bell', because of wide ozone absorption at the Hartley band [20].

Sampling of ozone at the wavelength $260.99 \mathrm{~nm}$ closely agrees with the data of the earlier works where the spectral range $253.65-280.00 \mathrm{~nm}$ has usually been chosen [1-5, 10-18]. Note that, in some of these works, the wavelengths 253.65 and $280 \mathrm{~nm}$ correspond respectively to mercury lamp and light emitting diode signatures, which are not easily changed. In this work we use a broadband light source. The optimal sampling wavelength $260.99 \mathrm{~nm}$ is selected for the ACS measurements. This is very important for increasing the sensitivity of measurements.

The maximum transmittance ratio value is difficult to obtain from Fig. 3. We have chosen the sampling wavelength of $260.99 \mathrm{~nm}$ for the $I_{t}$ parameter and the reference wavelength of $377.05 \mathrm{~nm}$ for $I_{0 r}$ to sample ozone with the ratiometric method. Notice that a very close wavelength, $377 \mathrm{~nm}$, has already been used in some earlier works as the reference wavelength for calculating the ozone concentration with the ratiometric method [15, 21, 22]. This is because the absorption at $377 \mathrm{~nm}$ is not sensitive to the ozone concentration changes. For instance, it is known that the ozone ACS at $377.5 \mathrm{~nm}$ is negligible $\left(\sim 4.4 \times 10^{-29} \mathrm{~m}^{2}\right.$ molecule $\left.{ }^{-1}[23]\right)$.

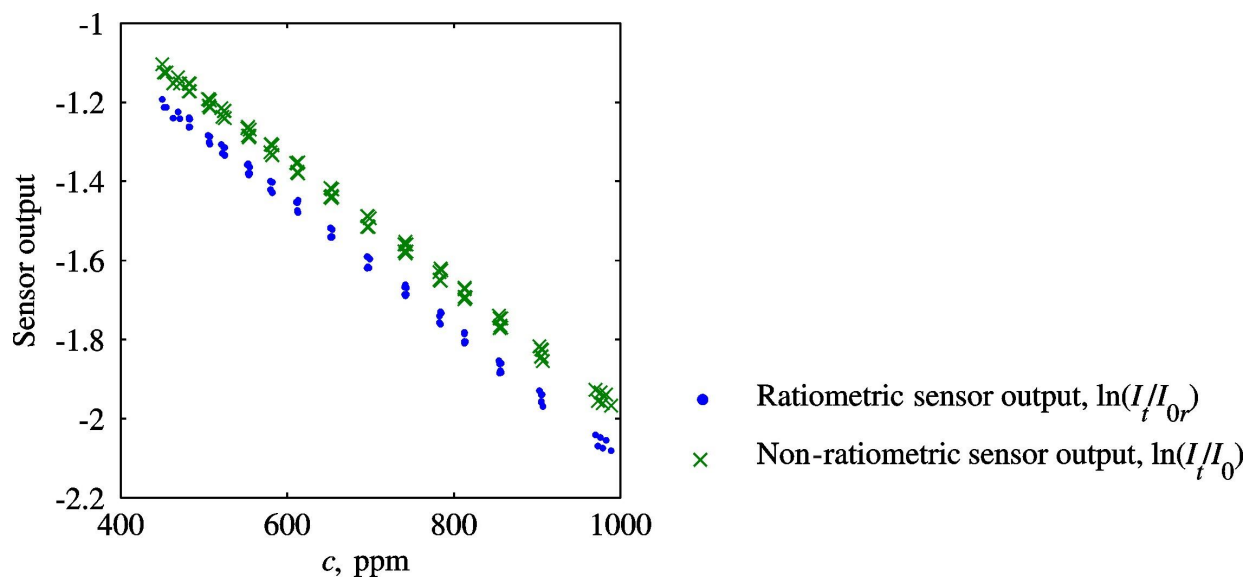

Fig. 4. Ozone concentration sensor output versus the ozone concentration, as obtained with the ratiometric and non-ratiometric methods.

In Fig. 4 we present the dependences of sensor output versus the ozone concentration measured in the experiments performed with the ratiometric and non-ratiometric methods. As seen from Fig. 4, the higher the ozone concentration, the lower the sensor output is. Here we deal with the linear dependences and the signal $I_{t}$ is reduced due to absorption of light.

The range of ozone concentrations represented in Fig. 4 is $450-989$ ppm. There would have been experimental difficulties with broadening this range due to limitations of our equipment. Note also that a Longevity Resources corona discharge ozone generator generates can probe a minimum concentration $450 \mathrm{ppm}$ with the times typical of our experiments (see Fig. 4), whereas a 2B Technologies ozone monitor 106-M is certified for measuring the ozone concentrations between 0.01 and 1000 ppm only.

The linear regression analysis based on MATLAB R2013a has shown that the best fits of the data displayed in Fig. 4 are described by the relationships 


$$
\begin{aligned}
& \ln \frac{I_{t}}{I_{0}}=-0.0015778 c-0.40245, \\
& \ln \frac{I_{t}}{I_{0 r}}=-0.0016359 c-0.46493 .
\end{aligned}
$$

After comparing the slopes of the fitting lines with Eqs. (1) and (2), one can deduce the ACS of ozone. The temperature $T$ in our experiments has always been kept stable in the region $302.3-303.6 \mathrm{~K}$, with the average value $303.0 \mathrm{~K}$. The pressure $P$ has been measured to be between 0.9667 and $0.9673 \mathrm{~atm}$, with the average value $0.9669 \mathrm{~atm}$. These average temperature and pressure are used when determining the resulting ACS value.

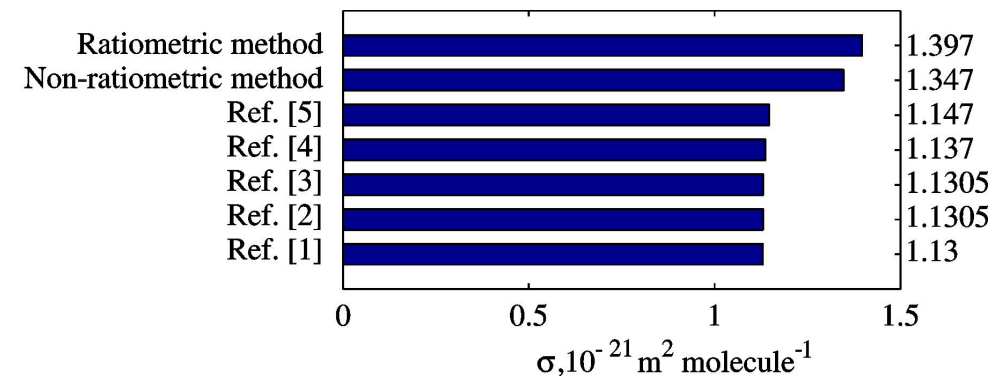

Fig. 5. Comparison of ozone ACS values reported in this work and in the earlier studies represented using a bar chart.

Fig. 5 compares the ozone ACS values obtained in this work and in the literature, using a bar chart [1-5]. In general, the ACS values obtained in this work (from $1.347 \times 10^{-21}$ to $1.397 \times 10^{-21} \mathrm{~m}^{2}$ molecule $\left.{ }^{-1}\right) \quad$ correlate satisfactorily with the data reported earlier $\left((1.13-1.147) \times 10^{-21} \mathrm{~m}^{2}\right.$ molecule $\left.{ }^{-1}[1-5]\right)$, although a systematic deviation of the order of $20 \%$ is observed. We cannot exclude that it is associated with some systematic errors peculiar to our equipment.

Another important point, however, is that our ACS value obtained with the non-ratiometric method $\left(1.347 \times 10^{-21} \mathrm{~m}^{2}\right.$ molecule $\left.\mathrm{e}^{-1}\right)$ is closer to the literature data than the value got with the ratiometric method. Indeed, the maximum deviation of our non-ratiometric data is at most equal to $19 \%$, as calculated using the formula $\left((1.347-1.13) \times 10^{-21}\right) /\left(1.13 \times 10^{-21}\right) \times 100$. Contrary to first-glance expectations, our ACS data obtained with the ratiometric method $\left(1.397 \times 10^{-21} \mathrm{~m}^{2} \mathrm{molecule}^{-1}\right)$ deviates stronger from that of the earlier works. The same simple estimation $\left((1.397-1.13) \times 10^{-21}\right) /\left(1.13 \times 10^{-21}\right) \times 100$ yields in $24 \%$. In other words, our ACS value obtained with the non-ratiometric method proves to be closer to the literature data, despite the fact that the method is not able to correct the reference intensity drift [17].

The latter fact may be due to relatively short duration of our experiments $(\sim 1400 \mathrm{~s})$. Indeed, it is known that the drift of intensity of a broadband light source can become negligible when the experiment is being conducted within short periods of time [14, 15, 21]. Then the both intensities $I_{0}$ and $I_{0 r}$ appear to remain stable throughout the experiment. Hence, our experimental results imply that the non-ratiometric method should not be necessarily regarded as inferior to the ratiometric one, at least in the case of short-period ACS measurements based upon the ultraviolet absorption spectroscopy. In the future, we would recommend longer-period experiments in order to compare more comprehensively the accuracies of the ACS measurements relying upon the ratiometric and non-ratiometric methods.

Ukr. J. Phys. Opt. 2015, Volume 16, Issue 1 


\section{Conclusions}

In conclusion, we have applied the ultraviolet absorption spectroscopy to measure the ACS using the ratiometric and non-ratiometric methods. We have obtained the values $1.397 \times 10^{-21}$ and $1.347 \times 10^{-21} \mathrm{~m}^{2}$ molecule ${ }^{-1}$, respectively. Our results testify that the relative deviation of our experimental data obtained with the non-ratiometric method from the literature data (not greater than $19 \%$ ) is higher than that typical for our ratiometric method ( $24 \%)$. Therefore, we would still recommend the non-ratiometric method for the short-period (restricted, e.g., to about $1400 \mathrm{~s}$ ) ACS measurements using the ultraviolet absorption spectroscopy. Nonetheless, extensive further work is advisable to compare the accuracies of the long-period ACS measurements with the ratiometric and non-ratiometric methods and to fix the reasons for rather large deviations of our data from the results known from the literature.

Acknowledgements. The authors are grateful to Universiti Teknologi Malaysia and Ministry of Higher Education, Malaysia for supporting this research work under the Research University Grant Scheme (grants No 05J60 and No 04H35), the Fundamental Research Grant Scheme (grant No 4F317), and the UTM Zamalah Fellowship.

\section{References}

1. Brion J, Chakir A, Daumont D, Malicet J and Parisse C, 1993. High-resolution laboratory absorption cross section of $\mathrm{O}_{3}$. Temperature effect. Chem. Phys. Lett. 213: 610-612.

2. Daumont D, Brion J, Charbonnier J and Malicet J, 1992. Ozone UV spectroscopy I. Absorption cross-sections at room temperature. J. Atmos. Chem. 15: 145-155.

3. Malicet J, Daumont D, Charbonnier J, Parisse C, Chakir A and Brion J, 1995. Ozone UV spectroscopy. II. Absorption cross-sections and temperature dependence. J. Atmos. Chem. 21: 263-273.

4. Voigt S, Orphal J, Bogumil K and Burrows J P, 2001. The temperature dependence (203-293 $\mathrm{K})$ of the absorption cross sections of $\mathrm{O}_{3}$ in the 230-850 nm region measured by Fourier-transform spectroscopy. J. Photochem. Photobiol. A: Chem. 143: 1-9.

5. Hearn A G, 1961. The absorption of ozone in the ultra-violet and visible regions of the spectrum. Proc. Phys. Soc. 78: 932-940.

6. Marcus T C E, David M, Yaacob M, Salim M R, Ibrahim M H, Ngajikin N H and Azmi A I, 2013. Absorption cross section simulation: a preliminary study of ultraviolet absorption spectroscopy for ozone gas measurement. J. Teknol. 64: 95-98.

7. Campbell I M. Energy and the atmosphere: A physical-chemical approach. $2^{\text {nd }}$ Ed. Chichester: John Wiley \& Sons Ltd (1986) pp. 12-14.

8. Clark B J, Frost $\mathrm{T}$ and Russell $\mathrm{M}$ A. Techniques in visible and ultraviolet spectrometry. Volume 4: UV spectroscopy, techniques, instrumentation, data handling. Boundary Row, London: Chapman \& Hall (1993) p. 6.

9. Bass A M and Paur R J. The ultraviolet cross-sections of ozone: I. The measurements. In: Zerefos C S and Ghazi A (Eds). Atmospheric Ozone. Netherlands: Springer (1985) p. 606-610.

10. Degner M, Damaschke N, Ewald H, O'Keeffe S and Lewis E. UV LED-based fiber coupled optical sensor for detection of ozone in the ppm and ppb range. IEEE Sensors Conference. Conf. Proc. (2009) pp. 95-99.

11. Degner M, Damaschke N, Ewald H and Lewis E. High resolution LED-spectroscopy for sensor application in harsh environment: a sensor system based on LED-light sources and standard photodiode receiver is shown as an example of this sensor concept for in-situ gas measurements 
down to the ppb range. IEEE International Instrumentation and Measurement Technology Conference. Conf. Proc. (2010) pp. 1382-1386.

12. O'Keeffe S, Ortoneda M, Cullen J D, Shaw A, Phipps D, Al-Shamma'a A I, Fitzpatrick C and Lewis E. Development of an optical fibre sensor system for online monitoring of microwave plasma UV and ozone generation system. IEEE Sensors Conference. Conference proceedings (2008) pp. 454-457.

13. Aoyagi Y, Takeuchi M, Yoshida K, Kurouchi M, Araki T, Nanishi Y, Sugano H, Ahiko Y and Nakamura H, 2012. High-sensitivity ozone sensing using $280 \mathrm{~nm}$ deep ultraviolet light-emitting diode for detection of natural hazard ozone. J. Environ. Prot. 3: 695-699.

14. O'Keeffe S, Dooly G, Fitzpatrick C and Lewis E, 2005. Optical fibre sensor for the measurement of ozone. J. Phys.: Conf. Ser. 15: 213-218.

15. O'Keeffe S, Fitzpatrick $\mathrm{C}$ and Lewis E, 2007. An optical fibre based ultra violet and visible absorption spectroscopy system for ozone concentration monitoring. Sens. Actuators B: Chem. 125: $372-378$.

16. Maria L D and Bartalesi D, 2012. A fiber-optic multisensor system for predischarges detection on electrical equipment. IEEE Sens. J. 12: 207-212.

17. Maria L D, Rizzi G, Serragli P, Marini R and Fialdini L. Optical sensor for ozone detection in medium voltage switchboard. IEEE Sensors Conference. Conf. Proc. (2008) pp. 1297-1300.

18. Maria L D and Rizzi G, 2009. Ozone sensor for application in medium voltage switchboard. J. Sens. 2009: 1-5.

19. Yehia A and Mizuno A, 2013. Ozone generation by negative direct current corona discharges in dry air fed coaxial wire-cylinder reactors. J. Appl. Phys. 113: 183301-1-183301-10.

20. Matsumi Y and Kawasaki M, 2003. Photolysis of atmospheric ozone in the ultraviolet region. Chem. Rev. 103: 4767-4781.

21. O'Keeffe S, Fitzpatrick C and Lewis E. Ozone measurement using an optical fibre sensor in the visible region. IEEE Sensors Conference. Conf. Proc. (2005) pp. 758-761.

22. O'Keeffe S, Fitzpatrick C and Lewis E, 2005. Ozone measurement in visible region: an optical fibre sensor system. Electron. Lett. 41: 1317-1319.

23. Brion J, Chakir A, Charbonnier J, Daumont D, Parisse C and Malicet J, 1998. Absorption spectra measurements for the ozone molecule in the $350-830 \mathrm{~nm}$ region. J. Atmos. Chem. 30: 291-299.

Marcus Tay Ching En, Ibrahim Mohd Haniff and Ngajikin Nor Hafizah 2015. Measurements of ozone absorption cross section with ratiometric and non-ratiometric methods. Ukr.J.Phys.Opt. 16: $61-67$

\begin{abstract}
Анотація. В ультрафіолетовій спектроскопї поглинання перетин поглинання (ПП) $\epsilon$ важливим параметром для розрахунку концентрації озону. У иій роботі визначено ПП за кімнатної температури та нормального тиску. Конщентрацію озону вимірювали за допомогою компактної алюмінієвої газової комірки з довжиною оптичного шляху 5 см при концентраціях озону 450-989 млн ${ }^{-1}$. Ми також порівняли результати, одержані за логометричним і нелогометричним методами, які базуються на законі Бугера-Ламберта-Бера. Дані наших експериментів засвідують, що нелогометричний метод може конкурувати з логометричним методом, якщсо лише часи вимірювань порівняно малі.
\end{abstract}

